\title{
Confronting the Reckless Gambling With People's Health and Lives: Urban Solid Waste Management in Zimbabwe
}

\author{
By \\ ${ }^{1}$ Enock C.Makwara and ${ }^{1}$ Snodia Magudu
}

\begin{abstract}
Litter has become a common sight along high ways and in many urban and peri-urban communities in Zimbabwe. In spite of the numerous clean-up and anti-litter campaigns that have been initiated by different individuals and organizations coupled with the tremendous effort that has been put in making the public aware of the disadvantages associated with littering, endemic and insistent filth engulfs Zimbabwe as people continue to litter. Zimbabwe's waste management has virtually collapsed, triggering chaotic and rampant waste dumping, putting the health of residents at great risk. The prevalence of various forms of litter in these communities has been fuelled by a consumerist corporate and social culture where a lot of packaged foodstuffs are manufactured to be consumed on the run. Inefficient collection mechanisms by municipalities and lack of 'separate at source' models have led to adverse effects on our ecosystem and the environment. Litter has primary and secondary effects on the environment and the community. The corporate world is affected by disease outbreaks as employees are either directly or indirectly affected. Considering that most industries are located within the vicinity of high density areas, their industrial waste management systems are also a cause for concern. Considering all the above mentioned factors, the paper examines ways and means of effectively managing waste in Zimbabwe's urban areas to reduce the exposure of people and the environment to waste hazards. The paper argues for the building of some environmental awareness and changing the mind-set of ordinary Zimbabweans to a set-mind where litter should be everyone's concern .It argues for waste disposal to be done in accordance with the best principles of public health, economics, engineering conservation, aesthetics and other appropriate environmental practices. The major conclusion is that there is urgent need for sustainable waste management chiefly through community participation and concomitant attitude change to adopt a 'trash is treasure, waste is wealth and refuse is resource' one.
\end{abstract}

Key Words: Waste, Waste generation, Waste management, Recycle, Reduce, Reuse

\section{Introduction}

Waste generation and disposal are grave environmental challenges in many urban areas particularly in developing countries. Waste generation in these 
countries continues to grow due to economic growth and changing consumption patterns. Our current lifestyles and activities are producing vast quantities of waste (United Nations Environment Programme [UNEP]-International Environment Technology Centre [IECT], 2003).The affluence of western societies has given rise to unprecedented quantities of waste, presenting one of the most intractable global environmental problems. All production processes invariably produce waste yet its management, especially in third world countries, leaves a lot to be desired. Whereas waste generation is on the rise, levels of collection are deteriorating. However, growing environmental awareness, restricted finances and a declining abundance of natural resources are demanding a change in waste management practices.

An aggregation of human settlement always produces large amounts of waste. Waste generation is intractably linked with resource consumption .The collection, transfer and disposal of that waste have generally been assumed by municipalities even though the format might vary (Zerbock, 2003). The current lifestyles and high resource consumption patterns have had unintended impacts on the urban environment. Cities are now grappling with problems of high volumes of waste, high costs involved in its management and its impact on humans and the environment. Three key trends can be observed with respect to waste vir:

* shear increase in volume of waste generated by urban residents;

* change in make-up of waste generated, and

* disposal of waste by landfills, incineration etc.

These trends are indicative of the issues that are central to the challenges of waste management in Zimbabwe.

\section{Solid Waste}

Waste has been variously defined Jackson and Jackson (1998) define waste as any movable substance or material that is perceived to be of no further use and therefore should be discarded. Generally, waste can be regarded as any material that is discarded because it has saved its purpose or is no longer useful. However, not all waste should be discarded as some can be transformed into useful products through recycling (Miller, 1994). Solid waste comes in various forms such as garbage, rubbish and dirt that accumulate in residential, commercial, industrial and institutional areas of towns and cities (Botkin and Keller, 2000). Therefore solid waste is the unwanted, useless and discarded non-liquid waste materials arising from domestic, commercial, manufacturing and trade industries as well as public service. Waste is generally considered hazardous and therefore toxic to the biological environment, including urban lifestyles and economic activity (Ireen, 2008). Therefore, there is need to manage waste as it poses danger to ecosystem and human health alike (Mapira, 2011). 


\subsection{Solid Waste Management}

Solid waste management refers to a range of activities in the handling of waste and should be understood to mean activities such as generation, storage, collection, transportation, processing, treatment and disposal of waste (Booth et al, 2001). Waste disposal should be done in accordance with the best principles of public health, economics, engineering conservation, aesthetics and other environmental considerations. Ideally, waste should be transported in closed vehicles to avoid the loss of some of the waste along the way and to prevent the spread of bad odours from the waste being transported (Jackson and Jackson, 1998). Regular collection and transportation prevents the piling up of the refuse which would end up creating breeding conditions for vermin. Waste management should be done in the framework of administrative, financial, legal, planning and engineering functions. According to Chiwandamira (2000), the goal of waste management is to ensure that its disposal does not lead to environmental pollution or degradation. This means that waste management should be undertaken in such a manner that garbage handlers, the public and the environment are not endangered in any way (Makwara, 2011). Therefore, waste disposal sites should be located reasonably far away from human habitation to prevent the migration of vermin and odours to people's homes (Jackson and Jackson, 1998).Booth et al(2001) contend that the disposed waste should ideally be covered with soil or be sprayed so that disease vectors will not breed and spread diseases. Because financial and material resources are lean in developing countries, this may not be adhered resulting in serious environmental problems (Katyal and Satake, 2001).

\subsection{Nature of the Solid Waste problem in Zimbabwe}

Zimbabwe spans an area of $390590 \mathrm{~km}^{2}$ and is divided into rural and urban areas. There are roughly twenty five [25] urban local councils in the country which exist in some continuum ranging in size and complexity from growth points to towns and cities. In Zimbabwe, like in most third world countries, waste generation is still at relatively low levels but there is less scope for reduction. However, studies pertaining to waste management in Zimbabwe by, among others, Tevera (1995), Moyo (1997), Masocha and Tevera (2003), Mapira(2007) Mapira and Mungwini (2007), Makwara (2011) and Mapira, (2011) show that, because of lack of capacity to manage it, solid waste is one of the most visible and pressing urban environmental problems. Therefore waste management has emerged as one of the greatest challenges facing local authorities throughout Zimbabwe. Most urban agencies and local authorities in Zimbabwe have time and again identified solid waste as a major problem that has reached proportions requiring drastic measures, notably from the 1990s up to the present. Chidavaenzi (2006) observes that urban growth in Zimbabwe continues at a much faster rate 
than the provision and expansion of infrastructure and services. Demographic changes and economic growth contribute to the generation of waste. Consequently, waste management has become woefully inadequate as is evidenced by the rise in illegal dumping and the proliferation of the now seemingly permanent piles of rubbish in some commercial, industrial and residential areas of the urban areas.

Nhete (2005) argues that in Zimbabwe, waste collection has virtually collapsed triggering its chaotic and rampant illegal dumping. Newspaper reports have shown waste accumulated in streets, often blocking drains. The waste is characterized by vegetative matter, tins, glass, cans, metals polythene, and wood among others. The concoction of such waste tends to be hazardous. If improperly handled and disposed of, it can cause substantial harm to human health, death of smaller animal and plant organisms and a general breakdown and loss to the immediate ecological systems. An Italian Environmental Association estimates that some wastes could live up to 100 years before decomposing and degrading completely in the environment (Green Living Tips 2009).If the decomposition process is completed, these materials cause inestimable pollution to the environment. This way living biological components, normal cycles, nutrient flows and the interrelationships existing among biotic organisms get disrupted by the presence of waste. People blight the environment through their reckless, selfish and uncaring attitude. Residents characteristically dispense of the waste they generate without regard for the environment since it is treated as common property. Chaotic dumping of both domestic and industrial waste has become a public health concern as it puts the health and safety of residents and that of the entire environment at great risk due to the toxic nature of some of the wastes. Uncollected and improperly treated organic wastes are sanitary hazards and sources of public nuisance, especially in densely populated urban areas. Waste dumps are sources of environmental problems such as aesthetic intrusion, overpowering stench from rotting waste and smoke emissions besides being potential sources of diseases. Open dumps are breeding places for vermin and other vectors of communicable diseases such as diarrhoea, dysentery and typhoid. At the onset of the rainy season, deteriorating environmental conditions caused by poor waste disposal techniques result in the blockage of drainage, flooding, surface water contamination and ground water pollution. In the process, vital aquatic resources get affected.

Waste generation is said to be a function of social status. Low income people are said to generate more waste than medium and high income people (Cointreau,1982).A far greater proportion of urban residents in Zimbabwe reside in the high density suburbs. Not surprisingly, most of the illegal waste dumping takes place therein, consequently, waste's impacts are more pronounced in the high density residential areas due to the constant pressure of human activity and 
high population densities on the immediate environment. The result is nothing but litter-infested, filthy and unsightly surroundings that generate public revulsion. In Harare, Bulawayo and Chitungwiza, practically every low income residential area has heaps of waste strewn all over. Add to this the sewage sludge from burst pipes across the cities' sprawling low income suburbs and the increasing number of people littering, urinating and defecating in open places [See Plate 1]. These are the directly visible effects of badly managed waste.

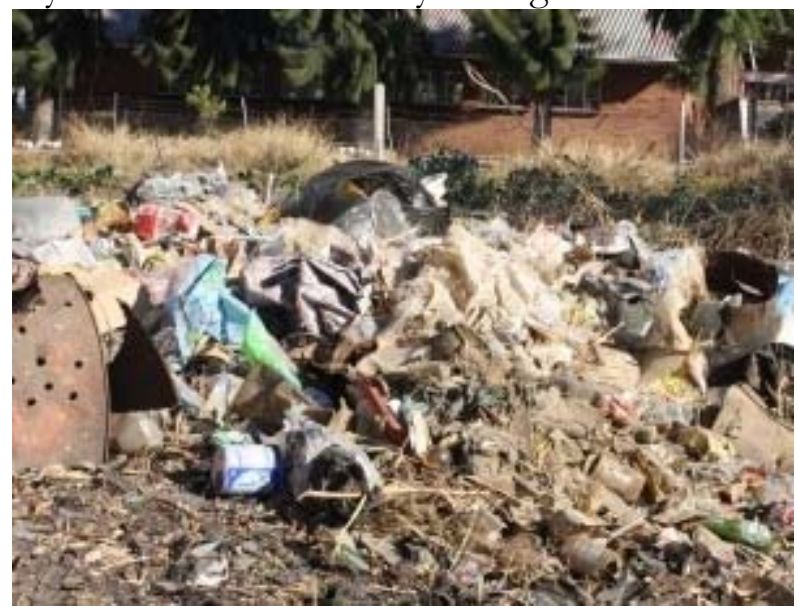

Source: Newsday 8 June, 2012

Plate 1: council refuse collectors are failing to collect garbage and most residents have resorted to dumping in the open space/nearby bush surrounding houses

The technical and administrative capacity to properly implement sound mechanisms for waste management is weak. This can be traced to lean financial, human and material resources which bedevil councils.It is worrying that Zimbabwe still lacks appropriate and effective technologies in waste management.In addition, the country's deteriorating infrastructure has resulted in poor waste management which has seen an accumulation of waste and outbreaks of diseases (Machivenyika,2012).

The provision of sanitation in most urban centres in the country is grossly deficient. Most people do not have access to hygienic toilets owing to water shortages and the mushrooming of informal settlements.Large amounts of faecal waste are discharged to the environment without adequate treatment. This is likely to have major impacts on the infectious disease burden and quality of life (Hutton et al. 2007). The lowest point in Zimbabwe's economic meltdown was when a cholera epidemic (2008-9), which literally engulfed the country, needlessly claimed the lives of not less than 4200 lives (The Zimbabwean on Sunday, 18 April, 
2010). The 2008 cholera outbreak in Zimbabwe can be traced to the collapse of waste management in the country.

Waste management systems that municipalities have in place serve only the formal settlements in their respective areas of jurisdiction. However, extensive informal settlements that have emerged in most urban centres are generally not served by the waste management systems. Waste management systems in these areas are currently in very poor standing and are largely dysfunctional. The sewerage system does not serve informal settlements so pit latrines and open defecation are widespread (Makoni et al 2004; Zingoni, 2005 and Practical Action 2010)

While Zimbabwe produces less per capita solid waste than developed countries, the volume of waste being generated continues to increase. The rate of waste generation by far surpasses the rate of municipal authorities' improvement of the technical and financial resources needed to parallel this growth. Its capacity to collect, process and dispose waste is limited in view of inadequate infrastructure, finance, political priority and awareness. Low collection levels and rudimentary disposal methods employed are a cause for concern because they trigger illegal dumping and rampant waste burning, which not only threaten public health but also pollute the environment.

\section{Challenges of Urban Waste Management}

Until the mid-1990s, Zimbabwe's urban centres were regarded as models of cleanliness in Africa and beyond. However, the scenario drastically changed as innumerable challenges that compromise waste management and disposal standards in the country emerged. Since the mid-1990s, Zimbabwe's economy has been on downward trajectory owing to the introduction of the Structural Adjustment Programme (ESAP) and the infamous land invasion which triggered the unprecedented economic meltdown in the country's history. This negatively impacted on municipalities which depend heavily on government and donor funding. To the urban poor, waste management has been a nightmare as they have little if at all any options. Streets in their areas are full of stench from rotting garbage. This is exacerbated by homeless people who defecate in open places and rank marshals who pour urine in plastic bottles while used condoms litter their streets. Municipal Councils, the duty bearers, can not collect the refuse regularly for a variety of reasons.Among others, there simply was no fuel,frequent breakdown of waste collection vehicle or they are in a state of disrepair or planning aids like resources and professionals involved in local government are not available due to the economic downturn.Both human and financial resources were simply not avilable under the hyper-inflationary environment .Urban authorities became incapacitated to deliver services. The standard of waste management continued to fall way below accepted standards with town councils 
failing to collect waste around their areas of jurisdiction regularly as scheduled.Residents waited in vain for refuse trucks and eventually emptied their refuse bins on any available open space until these became unreachable and the trash encroached onto the roads, blocking and barricading most places. City environments became an eyesore due to waste and the stench that emanated from the waste was so severe and overpowering. Currently, more than 2, 5 million tonnes of household and industrial waste are produced in Zimbabwe's urban areas per annum and this continues to rise due to unprecedented rural flight and the absence of minimization strategies (Practical Action, 2005). According to Chidavaenzi (2006), the last forty five (45) years have witnessed a 50\% decline in the density of waste being generated (460 to $230 \mathrm{~kg} / \mathrm{m} 3$ ) while the volume of waste has increased two-fold and the trend is projected to continue rising. The past ten years in Zimbabwe have been challenging for local authorities' management systems, service delivery, primary social infrastructural development, planning and organization (Chikuruwo,2005). The majority of the local authorities have not been sufficiently attending to key services including refuse collection. Inadequate and inefficient waste management systems obtaining in the country are also a function rapid urbanization and inadequate funding of waste management services. The problem can also be traced to what may be regarded as the most critical factor: an unstable microeconomic environment characterized by hyper-inflation, shortage of foreign currency for purchasing vehicles and spare parts, lack of skilled manpower and the crippling fuel crisis.

Local government was also seriously affected by the withdrawal of donor support as from 1998, owing to the political differences between donor countries and central government. Prior to the withdrawal of external aid, local authorities tended to over-rely on external technical, material and financial assistance through such programmers as Urban 1 and 2, the Local Government Capital Development Programme, the Deregulation Programme, and the Rural District Council Capacity Building Programme. It is common knowledge though that to be dependent is to be disabled. Donor flight meant that municipal service delivery was left to degenerate, not just in technical and financial aspects, but also in terms of planning and administration.

Other sources of revenue for urban councils to finance capital procurement, institutional development and meeting overheads are levies paid by ratepayers and grants from the parent ministry [Ministry of Local Government, Rural and Urban Development]. However, both these sources have not been ceding the revenue as expected. Collection of revenue from ratepayers has been erratic as residents are also affected by the economic environment. Many ratepayers have defaulted on payment and municipalities have periodically indicated that they are owed millions of dollars in rates and service charges arrears by not only residents but also government departments. Urban council officials raised the concern that the 
parent ministry always belatedly approves their budgets resulting in local authorities charging uneconomic tariffs. The parent ministry directs that local authorities should not spend more than $28 \%$ of their budgets on salaries. However, most urban councils use far more than this proportion for salaries as they yield to relentless pressure from labour unions and worker's demands, thus further eroding the financial resources at the disposal of municipalities for service delivery. Besides, uncoordinated, confusing and contradictory local government legislation is in existence, for example the Provincial Councils and Administration Act and the Urban Councils' Act. These acts leave gaps and overlaps in local government matters. Local government legislation has not fully embraced the rights of citizens' participation in and objecting to local governance strategies, policies and decisions (Muchadenyika, 2012).Local government is an extension of central government. This implies that central government inhibits the nature, composition and functioning of local authorities. With central government performing poorly and full of bribery, corruption, budget deficits, and maladministration, it means local government is a mirror image of the bigger picture at central government. Indeed, a number of councillors have been and continue to be suspended and dismissed by the parent ministry for more to do with politics than service delivery. The intense debate to move and pass motions in councils had been a welcome development as significant service delivery had been witnessed in cities like Harare .Appointed Commissions, which showed a huge disconnect with residents, replaced elected councillors in among other towns Harare, Chitungwiza, Mutare and Chegutu. The commissions were incompetent so they distabilised and grounded service delivery mechanisms. Residents are still paying for this incompetence. The quality of existing waste management is determined by resources allocated to carry out the task and the efficiency of their use. Kativhu (2006) posits that putting the blame on the economic situation is an easy scapegoat as it implies that the situation cannot be improved until economic recovery takes foothold.

Local authorities have experienced serious technical and financial resource inadequacies to meet their refuse collection and disposal obligation, a traditionally critical component of local authorities' mandate. The volatile economic conditions induced difficulties in budgeting and planning processes of local authorities resulting in insufficient capital funds being devoted towards such critical areas as refuse removal, disposal and management. 
Table 1: Population Changes in Zimbabwe's Largest Cities/Towns

\begin{tabular}{|l|l|l|l|l|l|l|}
\hline & & $\begin{array}{l}\text { Populati- } \\
\text { on }\end{array}$ & $\begin{array}{l}\text { Populati- } \\
\text { on }\end{array}$ & $\begin{array}{l}\text { Populati- } \\
\text { on }\end{array}$ & $\begin{array}{l}\text { Populati- } \\
\text { on }\end{array}$ & \\
\hline Rank & City/Town & $\begin{array}{l}\text { Census } \\
1982\end{array}$ & $\begin{array}{l}\text { Census } \\
1992\end{array}$ & $\begin{array}{l}\text { Census } \\
2002\end{array}$ & $\begin{array}{l}\text { Estimate } \\
2007\end{array}$ & Province \\
\hline $\mathbf{1}$ & Harare & 656011 & 1189103 & 1444534 & 1607022 & Harare \\
\hline $\mathbf{2}$ & Bulawayo & 413814 & 621742 & 676787 & 713340 & Bulawayo \\
\hline $\mathbf{3}$ & Chitungwiza & 172556 & 274912 & 321782 & 352204 & Harare \\
\hline $\mathbf{4}$ & Mutare & 69621 & 131367 & 170106 & 193629 & Manicaland \\
\hline $\mathbf{5}$ & Gweru & 78918 & 128.037 & 141.260 & 148.935 & Midlands \\
\hline $\mathbf{6}$ & Kwekwe & 47607 & 75425 & 93072 & 103210 & Midlands \\
\hline $\mathbf{7}$ & Kadoma & 44613 & 67750 & 76173 & 81008 & Mashonaland West \\
\hline $\mathbf{8}$ & Masvingo & 30523 & 51743 & 69993 & 80630 & Masvingo \\
\hline $\mathbf{9}$ & Chinhoyi & 24322 & 43054 & 56794 & 65109 & $\begin{array}{l}\text { Mashonaland } \\
\text { East }\end{array}$ \\
\hline $\mathbf{1 0}$ & Marondera & 19971 & 39384 & 52283 & 60291 & Mashonaland West \\
\hline
\end{tabular}

Source:Central Statistical Office, 2002; Population Reference Bureau, 2011.

The situation is further compounded by pressure exerted by the ever increasing urban populations as councils grapple to fulfill their responsibility of service delivery as illustrated in Table 1.

Currently, Greater Harare for example, has to deal with three million (3 000000$)$ inhabitants (Muza, 2005).Harare alone has become an urban agglomeration with a population of about 2.3 million people (Brinkhoff, 2010). The issue should be understood against the background that waste management systems were designed for far lower urbanisation levels and far fewer people than what towns have to contend with. Consequently, refuse collection in the city has at best been erratic.

With the increase in population and living standards, commercial, domestic and industrial waste generation also rapidly rises as consumption increases. This has resulted in indiscriminate illegal dumping of waste by residents and the subsequent aesthetic intrusion. The absence of forward planning and the proliferation of residential areas without the proportional expansion of primary social services infrastructure are factors that have contributed to the current water, sewerage and waste woes.

Large volumes of waste and the crude disposal techniques have created subtle yet serious environmental pollution in the country's urban centres. This has resulted in the degradation of both the biotic and abiotic components of the nation's ecological systems. Poor waste disposal systems as well as indiscriminate and inappropriate domestic litter disposal have been identified and proven to be basic features in rural, semi-urban and urban centres. The major reason for this has been identified to be lack of knowledge on the part of the residents about the 
risks associated with improper waste disposal and insufficient modern waste disposal facilities.

The growth of urban populations has been accompanied by a proliferation of vendors whose activities contribute significantly in blighting the environment. In most high density suburbs, the word clean environment no longer applies and it also seems as if it will never apply at all. Residential areas are swamped by vendors selling their wares everywhere despite that there are designated places to carry out such kind of activities. Open fast food stalls have mushroomed in urban centres. While local authorities claim to disapprove of this, at least on paper, they seem to lack the will power to contain illegal vending. Such activities are usually controlled through licencing but this option seems to have failed to produce the desired results. This is evidenced by the presence of vendors allover the towns who generate all kinds of waste which is found strewn all over .

Problems emanating from municipal solid waste can lead to serious consequences including pollution. Pollution includes the crude and poor industrial waste disposal as well as the indiscriminate and inappropriate domestic litter disposal habit evident in public places. The increase in the number of commuter omnibuses and taxies has resulted in the increase of rank marshals and 'bwindis'(touts) within towns. These people pollute the streets and service lanes, that are used as entry points for deliveries for several shops and businesses to particular buildings, with faeces, used condoms and and a whole range of plastics. Available public toilets cannot sustain the daily demand of all these people. In addition, public toilets at bus terminal, which are usually next to fruit and vegetable markets, are rarely cleaned thus posing a serious health hazard. While street kids are usually blamed for the mess, the generality of the citizenry also contributes. Some residents simply have the attitude that someone will pick up the litter they would have discarded anywhere and anyhow instead of disposing of it properly in the trash can or dustbin.

There are other problems that have brought about the ubiquitous mounds of unmanaged solid waste. These include the use of vehicles that do not compact waste, the absence of regular monitoring of quantities and composition of solid waste, changes in consumption patterns and the unavailability of legislation that penalises littering. Waste policy is virtually ineffective and inefficient. Few clauses of municipal ordinances are the basis of waste management. Zimbabwe, albeit belatedly, made a milestone development by promulgating a piece of legislation (Environmental Management Act [EMA]) in 2002 that integrated and harmonized a myriad of acts that were previously administered by different government ministries to safeguard the environment (Gandiwa, 2004).EMA superintendents all activities in the environment as it has been mandated to be the watchdog of the environment (Shava, 2003). Responsibilities of waste generators and or municipalities are not spelt out in detail thus limiting the mandate of local 
authorities. The ever increasing waste, cost ineffective legislation and inefficient institutional image have made solid waste a very challenging task for local authorities. The situation demands a paradigm shift, from the existing waste management regime, to one where perhaps local authorities, the private sector and the community can collaborate as stakeholders to improve the situation.

The dilapidation of the living environment in urban centres has raised many questions than answers for the responsible authorities. In spite of the dollarisation of the economy, waste management has not improved to its previous level. Local authorities are still in a vulnerable position with respect to fulfilling their obligations as indicated by the erratic and infrequent waste collection. They are still struggling to fulfill most of their functions despite the improved economic conditions since the formation of the inclusive government in 2009. The task of collecting, treating and disposing of solid waste presents complex technical challenges. It too poses a wide variety of administrative, economic and sociocultural problems that must be managed and resolved in the country's urban areas.

Filthy habitats are evident when people thoughtlessly make a mess of public utilities, office premises and streets, parks and neighborhoods. An outcry by ratepayers, demanding an improved service delivery resonated in many towns but this came to naught. Although third world countries spend between $20 \%-40 \%$ of municipal revenues on waste management, this is often unable to keep pace with the scope of the problem.

\section{Whither Zimbabwe? Way forward for Effective Waste management}

The general assumption is that solid waste management should be done at town level. As a result, only end of pipe solutions have essentially been tried. Thus solutions to the waste problem are attempted at the final stage of waste's cycle of causes and effects. With respect to urban waste, it means focusing on waste disposal rather than waste reduction at source, recycling or reuse. Such an approach misses the forest for the trees in attempting piecemeal solutions to the waste problem instead of taking a holistic long-term approach. There is need for a change in the existing waste management regime. A number of critical actions need to be taken at household, commercial enterprise, neighbourhood, town and national levels.

Robust public awareness campaigns on the need to properly dispose waste are vital. In order to raise awareness of the litter problem in our communities, the media could play a key role. Radio, Television and Press could be used to disseminate material on litter. Municipal Public Relations Departments should engage the media as much as possible on the subject. Various messages, running on different themes, targeting various audiences would need to be compiled. Such 
campaigns should be designed to sensitize the public to appreciate that littering is shameful and that there is value in reducing, recovering, recycling and reusing waste. Prominent figures, specialists and special interest groups could be featured in anti-litter campaigns such as radio talk-shows on litter. Zero litter jingles could be created and featured on radio as often as possible. Billboards featuring prominent social figures in zero litter adverts can be erected in urban centres and along major highways. In addition, zero litter generation primary school essay competitions could be launched. At secondary school level, open talk on litter competitions could be encouraged. The formation of zero litter Zimbabwe school clubs could also be launched while musicians can be approached and asked to make zero litter Zimbabwe part of their performance routine. Flyers and Council Health Departments' outreach programmes could come in handy.

Litter is a state of mind so it is the mindset that is the root of the problem. It is directly related to the character of a nation. In order to address the litter issue, there must be a change in the public's perception of litter. People should improve communities they live in. This can be achieved through the media and social networking besides emphasizing the importance of public social responsibility. Many corporate bodies have invested thousands of dollars in clean-up events. These noble initiatives only have short-term effects on communities. There is need for lasting solutions. If litter is a state of mind, a moral issue directly related to our character as a nation, the nation should seek to change the public's attitude towards refuse disposal. The answer to the country's litter woes lies in people's mindset and restoring in people a sense of pride in their country so communities should be incorporated as collective effort is required in this regard. Although clean-up events are necessary, it is important to focus on zero tolerance to litter. School teachers and school children should be key players in the community education drive. Even more importantly, attention should be focused on recycling strategies and options. Perhaps the 'separate-at-source' system could be introduced as councils seek to address the litter scourge that has for a long time bedeviled the country. This could provide the ultimate solution considering how litter has managed to make the country lose its previous luster. Target populations should be churches, schools, entertainers, and prominent figures in communities, commuters as well as the corporate sector. The NGO community, government, relevant government ministries, environmental bodies and the general public need to be incorporated. Zero litter training seminars could be held in urban centres starting with big metropolitan centres. Such a programme would have to reach school children who can then initiate zero litter generation clubs. However, there is need to start by addressing refuse collection and disposal infrastructural deficiencies perhaps through close partnerships with local authorities and stakeholders. 
Waste disposal baskets, refuse drums and trash cans should be visible on the streets, roads, parks, highways and other public places. These facilities were once in place but they have largely been vandalised, ignored or abandoned. Their animations could be used to indicate that they are meant for waste disposal. Demonstrations and illustration of proper waste disposal can be shown repeatedly on television, webs, billboards, radio jingles, flyers and local announcements. The hazardous and toxic effect of environmental pollution could be demonstrated by the unpleasant sight and offensive nature of domestic sewage and industrial waste, city drainages and open waters.

Environmental damage and detrimental effects that often result from improper disposal of non-readily biodegradable materials such as plastics, nylon, bags ,tins, cans, glass and metal objects among others, are immense but immeasurable. To help the situation, industrialists could initiate promotions and declare incentives for the collection of throw-away packs. Better still, they can help in environmental cleaning and sanitation programmes by providing, along with their products, guidelines on how to properly dispose their by-products or packs (Intergovernmental Panel on Climate Change, 2006). They can also provide trash cans with their logos for doing so, thereby not just helping to manage waste but also advertising their products.

\subsection{Policies Meant to Facilitate Effective Waste Management}

Another important measure would be for both central and local governments to craft and invoke policies, regulations and laws that are meant to implement the polluter-pays principle. This would complement waste management initiatives by waste generators themselves. Composting initiatives could be promoted through government policy on waste management, particularly organic waste management. A portfolio policy on intervention to solve the problem would demand and dictate that resources be marshalled to solve the problem. While a legislative framework for managing waste is in place in Zimbabwe (EMA), there is no enforcement. There appears to be an apparent reluctance by government departments to prosecute local authorities that violate provisions of the legislation. The implementation of EMA has been quite lethargic as indicated by the small number of offenders who have been either fined or tried for contravening the law. Another legislative weakness is that fines prescribed are too low, rendering effective enforcement difficult. The fines and sentences imposed for flouting the law are not deterrent enough. Interestingly, EMA provides for environmental entitlements for example the right to a clean environment, yet these rights are not enshrined in Zimbabwe's constitution and are difficult to enforce. Worse still, the intended beneficiaries of the entitlements are not aware of these rights hence the need for environmental education and awareness to ameliorate or better still circumvent the problem. 
Current legislation emphasizes end-of-pipe solutions rather than tackling them at the source via waste minimization through reduced product packaging by manufacturers and supermarkets selling, rather than giving plastic paper bags free. Statistics show that we throw away $20 \%$ of the food that we buy (http://www.gdrc.org/ucm/waste/3r.html.).Left over 'sadza' could be brewed into traditional maheu, instead of buying commercial maheu. Left-over food could be fed to domestic animals like pigs, dogs and chicken while old clothes can be stuffed into pillows rather than throwing them away.

EMA makes provision for waste management standards and regulations but these are not yet fully operational. Various estimates say urban waste collection is estimated to have dropped from at least $80 \%$ (in the mid 1990s) of waste generated to as low as 30\% in large and small towns throughout the country. Areas most affected by erratic waste collection are low income residential and informal settlements such as Jacha in Epworth which receive no formal waste collection at all. At least $70 \%$ of the collected waste is crudely tipped at open dump sites, $90 \%$ of which do not meet basic environmental standards (Tevera et al, 2003).

Globally, the UNDP estimates that more than five million people die each year from diseases related to inadequate waste disposal systems. In Epworth, there has been a recorded increase in cases of sanitation-related diseases such as diarrhoea, typhoid and dysentery and all of these arise from urban waste mismanagement. Curing affected people is far more expensive than preventing the diseases through effective waste management. For all the diseases analysed, there were gradual increases in their frequency of occurrence between 1999 and 2001 followed by steady decreases in 2002.However, since 2003, sharp increases were recorded (Chikuruwo, 2005).

The UN Centre for Human Settlement says between $25 \%$ and $55 \%$ of waste generated in large cities is collected by city authorities (http//www.gdr.org/ucm.waste/key factor html 04/08//10).Significant waste reduction takes time to achieve and requires large numbers of households to change their consumption patterns and daily habits. Households can compost their organic waste for their own use. In composting, micro-organisms decompose organic materials under certain conditions and reduce waste significantly. Composting can be applied at various scales from individual household up to large controlled facilities.

Compost can be sold or even given for free to farmers in the neighbourhood. Biodegradable waste like food and yard waste from households, institutions and small businesses can be reduced via composting thus minimizing their impact on the environment. It has been argued that mechanical biological treatment (MBT) can reduce the volume of waste by $40 \%$. This process entails a group of hybrid methods where re-assorted waste undergoes pre-treatment before disposal in 
landfills.MBT includes mechanical separation where recyclables like plastics and ferrous metals are removed and the organic fraction gets biologically treated. If the treated, waste may end up containing low levels of pollution. It can then be used for landscaping instead of being disposed in a landfill. Overall, composting produces a pathogen-free residual product that can be used for improving soil structure and the soil's water-holding capacity or adding nutrients to the soil. Composting residuals can be used as a resource for households or municipal governments if farmers are prepared to pay for the compost. This route has been tried and tested in the rural areas for a long time. Although risks such as bad smell, release of greenhouse gases and vector-borne diseases can occur if not properly managed, composting is neither complicated nor an economically unrealistic alternative compared to landfills. Composting can be labour intensive and therefore generate more jobs. It too requires low investment making it particularly attractive and suitable to introduce at very small scales. It is highly suitable for community driven waste management initiatives (Barton et al, 2008). From waste management, many varied issues arise and these have multifarious and far-reaching effects on the environment -biological, chemical, physical etc. For example, decomposition of organic waste under anaerobic conditions in solid dumpsites leads to the formation of biogas consisting of $50 \%$ methane, a potent green house gases(GHG)(IGPCC, 2006).Government policy on solid waste reduction, at all levels of the economy has relied on voluntary measures by waste generators since 1998. With this policy framework, local authorities have an important role to play in the way they manage waste locally. Government should formulate and implement policies for environmental protection. Common problems for municipal solid waste management in LDCs like Zimbabwe include institutional deficiencies, inadequate legislation, resource constraints while short and long term planning are inadequate due to capital and human resources limitations. There is need for financing Municipal Solid Waste Management, training specialists and capacity building.

Another strategy for sustainable urban solid waste management is to adopt a community based approach. New forms of civic engagement should emerge as has happened elsewhere in India, Bangladesh, the Philippines, Cambodia, Thailand and Vietnam. Community should be actively involved in the decisionmaking process of solid waste management. At community level, a communitybased solid waste management on the basis of some guidelines could be attempted. For example, the community might collaborate to improve the level of cleanliness in their neighborhood by establishing a compost plant, adopting their streets for sweeping, service drain cleaning and loading of household bins onto garbage trucks. At ward level, segregation of waste, segregated collection, selling of recyclables, composting of organic wastes and its marketing and monitoring schedule could be adopted as project steps. It is important to recognize that 
government support and acknowledgment is imperative in community-based initiatives. This can increase public trust and the legitimacy of the initiatives. While local authorities can take a leading role to institutionalize the informal communitybased activities within their formal waste management, effective decentralization and stakeholder participation can make solid waste management more flexible, efficient and responsive to local requirements and potentials.

\section{Devolution of responsibilities, authority and decision-making}

Looking at the life cycle of waste and reducing it at source at as many stages as possible can help to provide for alternatives and more sustainable ways of addressing the problem of urban solid waste management. Waste reduction can be achieved through recovery, re-using and recycling. Banning use of plastic bags, working with manufacturers and retailers to reduce packaging materials and using recyclable materials or home-based composting thus minimizing waste generation at source stage is also another useful strategy. Sorting waste at source and recycling and extracting methane (CH4) from landfills reduces waste at the collection and disposal stages. If all these strategies are employed, councils would register significant reductions in the waste that eventually reaches dumpsites, landfills and thus extending their life span and reducing street collection and disposal costs.

A necessary concurrent attitudinal change required is to adopt a "trash is treasure/cash" "or "waste is wealth" and "refuse is resource attitude". If such an attitude is adopted, a significant decline in waste to be collected and disposed can be achieved hence reducing the frequency of collection thus management costs. Estimates from several towns and cities of developing countries of Asia and the Pacific show that as much as $20 \%-30 \%$ of waste generated in cities is recycled by the informal sector (UNESCO Economic, and Social Council, 2006). This amount could be increased significantly. It would be even better if the informal sector recycling system comprises several categories of waste pickers who collect recyclable waste from households, dumpsites and municipal landfills. In Cambodia, China and Thailand, food waste is collected for animal feed on a relatively large scale (UNESCO Economic and Social Council, 2006).The idea of recycling has not been fully explored in Zimbabwe and has been confined to limited materials like plastic containers, etc. In addition, the public is not allowed access to rubbish dumps. There is need for public awareness on the idea of recycling, again, tapping on traditional knowledge so as to foster a sense of ownership among the public. Once the public is aware of the fact that unmanaged waste is their own disadvantage, they may get motivated to address the problem through maybe policing each other, reduction and reuse. 
Waste reduction at source should be regarded as the first step in the waste management hierarchy and this can go a long way in protecting the environment in a sustainable manner. Practical ways of reducing waste should be promoted at household, commercial and industrial levels (See Table 2). This suggests waste segregation at source which is critical in reducing waste going to the landfill. Segregation of waste should be done effectively and efficiently in an appropriate manner whether at home, office or industry. Segregation is vital to all the successive waste hierarchy components (recover, reuse, recycle and reduce).

\section{Table2: Practical ways of reducing waste}

\begin{tabular}{|l|l|}
\hline DOMESTIC & INDUSTRY/COMMERCE \\
\hline Purchase things with less packaging & $\begin{array}{l}\text { Change inputs-use resources more } \\
\text { efficiently }\end{array}$ \\
\hline $\begin{array}{l}\text { Purchase things that do not go out of } \\
\text { fashion quickly }\end{array}$ & $\begin{array}{l}\text { Change process-change layout if current } \\
\text { one is inefficient }\end{array}$ \\
\hline $\begin{array}{l}\text { Purchase durable items that will last } \\
\text { long }\end{array}$ & $\begin{array}{l}\text { Change outputs-design new control } \\
\text { systems; separate waste materials for } \\
\text { resource recovery }\end{array}$ \\
\hline Purchase refillable items & $\begin{array}{l}\text { Use less disposable items for example } \\
\text { paper cups, disposable plates }\end{array}$ \\
\hline $\begin{array}{l}\text { Bring a shopping bag instead of } \\
\text { buying or asking for a plastic or } \\
\text { paper bag }\end{array}$ & $\begin{array}{l}\text { Make few copies of a document to share } \\
\text { instead of making a copy for each }\end{array}$ \\
\hline Cook just enough food for the meal & $\begin{array}{l}\text { Buy just enough food and drinks for } \\
\text { meetings, seminars conferences events }\end{array}$ \\
\hline & Print both sides of the paper \\
\hline
\end{tabular}

Waste could be segregated as follows:

- biodegradable - kitchen waste, vegetables, fruits, flowers, leaves, dust. Some of the bio-degradable material can be used directly as feedstock for the production of biological and chemical conversion products.

- recyclables - plastics, paper, glass, rugs, rubber, leather, cartons, rexene. These can be either reused directly or indirectly or reprocessed. There are certain waste items which should be handled carefully e.g. old medicine bottles, paint cans, chemical containers, pesticide bottles and batteries among others.

Councils can advise hotels and restaurants to strictly adhere to the segregation of dry and wet waste and to keep them clean. At household level, such separation can be encouraged and be incorporated into urban councils' bylaws. One way of 
enforcing both reduction and separation would be to require every household to uploading their refuse bins onto refuse collection vehicles. Irene (2008) posits that the kitchen is the main source of waste production so it should be target number one for reduction via separation. Households could keep small containers to store waste in the kitchen and hand these to the collection crew who then dispose them in collection vans and return empty containers. Currently, mixed wastes are collected from households. Separation at source into organic, inorganic and hazardous wastes is not being practiced. In the long-term, delivery of household waste to landfills is not sustainable. The availability of suitable landfill sites is highly limited in most urban centres and land is needed for other purposes. Potentially valuable resources are lost when buried in landfills. Surrounding soil, plants, surface and underground water may be contaminated by substances leaching from the site and the degradation of organic materials generates $\mathrm{CH} 4$, a powerful greenhouse gas.

Besides their statutory obligations, local authorities are motivated by political concerns to provide solid waste services. They are lacking in both financial and institutional culture to train their personnel to build knowledge and capacity in waste management. Poor government policy and response, lack of political priority and transparency in budget use, bureaucratic and top-down approaches in decision-making have made solid waste management a complex activity. Substantial portions of budgets are devoted to collecting, transporting and disposing solid waste. Focus is on end-of-line solutions that are capital and technology intensive and therefore costly.

Local authorities should be innovative and pro-active in the way they manage waste. There is need to explore alternative options of waste management and also to initiate waste management programmes rather than sticking to refuse collection and disposal only. For a start, local authorities could get into partnerships for service delivery. Such partnerships should have a technology transfer component to ensure sustainability in the event that partners withdraw.

Local authorities are not aware of the quantities of domestic and industrial waste generated or the cost of service delivery. Consequently, refuse charges are not a reflection of the quantities generated or the cost of service delivery. It may be advisable to tie the charges to the quantity of waste generated. It may be necessary for local authorities to charge cost recovery refuse fees for sustainability. To this end, there is need to engage stakeholders in discussion and in these, there is need for openness and sincerity.

In community participation and the involvement of Community Based Organizations to eliminate illegal dumping, priority attention should be given to areas with high population densities. Furthermore, waste management systems from generation to disposal should be developed. There too is need to create a platform for creative and purposeful stakeholder engagement and participation in 
order to come up with practical solutions to the waste management challenges. Focus should be squarely placed on exploring ways of solving the problems rather than apportioning blame. There is need for stakeholder appreciation and contribution to the quest to find lasting solutions; after all, waste issues are best articulated by waste generators themselves.Chikuruwo (2000) posits that dependency on external assistance for development seems to have induced a worrisome degree of lethargy on our institution of development. It should be our collective responsibility to resolve to eradicate this mentality completely so that we become masters of our own destiny. Dependency tends to disable.

Following the donor pull out it dawned, in a painfully hard way to most development stakeholders that overreliance on external assistance at any level and for any purpose is pregnant with the potential of severe peril. There is need to recognize that the essence of decentralization of the local government system, inter alia, is to bring the citizenry closer to the decision-making processes and allow participation thus inducing a sense of ownership with respect to financial, human and material resources. This should be understood against the background that members of the public do themselves a lot of disservice by failing to adopt and nurture a culture of cleanliness. The environment belongs to everyone and therefore to nobody, hence it is treated as common property. Consequently, litter is thoughtlessly, recklessly and carelessly strewn all over in the mistaken belief that someone will clean it. The all-too-familiar Hardin's (1968) thesis “The Tragedy of the Commons" thus applies. Enforcement of anti-litter and refuse collection and management bylaws by local authorities is weak in part due to manpower levels. The absence of Municipal Courts specifically charged with the responsibility of trying and meting out punishment on municipal law offenders is yet another hindrance on the war against garbage disposal control in most urban areas (Chikuruwo, 2006). This is compounded by the absence of arresting powers on municipal police which has severely compromised their effectiveness in bringing to book municipal offenders. Apart from issuing tickets, the municipal police merely exercise citizen's arrest powers without necessarily dealing with the offence decisively and conclusively.

At community level, organized groups working closely with local authorities to coordinate the safe disposal and management of garbage arising from residential areas can play a significant role. It might be rewarding to create investment portfolios at councils which would be responsible for strategizing on income generation as is provided for in section 221 of the Urban Councils' Act (CAP 29:15).A focused and competently manned council investment portfolio has the potential of specializing in projects that would expand the revenue base of council while at the same time luring investment into the council's area of jurisdiction. According to Muza (2006), charging cost-effective and economic tariffs for services rendered is the way forward. There is need to explore Integrated Waste 
Management Systems to include recycling and waste conversion through strategic partnerships with the corporate world. In addition, it is necessary to seek outside funding to help recuperate the existing fleet, equipment and plants. In doing so, there is need for a zero tolerance to corruption which has come to reside with town councils and the country as a whole.

A case in point is when Harare City Council sought to augment its refuse collection fleet. Under controversial circumstances and against the advice of an internal evaluation that spare parts for tractors were not available, the Commission running Harare City Council went ahead and purchased twelve tractors from China. Newspaper reports say all the tractors broke down less than seven months after delivery.

\section{Policy}

The country needs to develop a national waste management policy, complete with a vision, mission, strategy and action plan. The strategy is to be based on creativity and should be results-driven because some of the problems are a result of lack of creativity by responsible authorities. Besides, relations between the parent ministry and local authorities need to be improved. The parent ministry and local authorities should stop concentrating on their differences and work together in solving environmental challenges bedeviling urban councils. The parent ministry should improve on its supervision of local authorities and not wait for disasters such as the catastrophic 2008 cholera outbreak to happen before it takes action.

Local authorities are urged to engage and encourage communities to take up recycling projects for income generation and sustenance. Councils should support small to medium enterprises that process recyclable waste and waste to energy conversions. Local authorities should also engage in public awareness and education campaigns. They too should cascade responsibilities to communities and other stakeholders. Chari (2006) argues that the community should reduce waste generation and reuse some of the waste at generation and storage stages over and above separating waste at source. Environment Africa's waste separation activities in Mabvuku and Tafara (Harare) have been an eye opener and a wakeup call to local authorities to be visionary. Environment Africa has been distributing flyers, mounting workshops and undertaking campaigns and providing receptacles. Communities can also be involved in the pre-collection of waste and the collection of recyclables. It is prudent for local authorities to announce collection dates at least 24 hour in advance so as to curb indiscriminate dumping of waste when people miss collection days. There too is need to take steps to 
reduce waste production. People should be trained in various aspects of integrated waste management as well as project management, lobbying and advocacy.

Environment action groups can be assisted to venture into hand-made paperrecycling projects. Environment Africa has done this in Harare's Mabvuku and Tafara high density suburbs through funding for the procurement of the requisite equipment such as bins, collection cages and push carts.

Urban farmers have also been urged to use in-situ composting and backyard composts for nutritional gardens through Environment Africa's urban agriculture component. Environment Africa has been implementing recycling projects with other community groups in Bindura, Mutare in addition to Harare's Avondale and Dzivarasekwa low and high density suburbs respectively. Such projects need to be made more visible and should be expanded.

Prices paid by the national waste collection companies for waste need to be revised upwards, notably recyclable paper because as long as the prices remain low and depressed, the incentive to recycle is removed. Councils should also be lobbied to allow those with their resources to organize transport to collect waste from the suburbs to deposit at official dumpsites free of charge. Monavale residents (Harare) have been mobilizing their own resources and organizing transport to collect waste from their suburb for depositing at the city's dumpsite. Civic pressure and litigation may be applied against local authorities who abdicate their responsibility. This has been done in Mutare and Harare in collaboration with the Environment Law Association. Challenges have to be anticipated in the process. For instance, Environment Africa reports that it has encountered a number of challenges. Among the challenges are:

- lack of community awareness of environmental rights as proposed in legislation;

- lack of access to environmental information;

- poverty , meaning that waste management is not a priority and

- negative attitude by communities and non-enforcement of laws.

A complete re-thinking of waste management is essential. In Epworth, the community is involved in waste management through a community based environmental action group and a refuse collection and recycling project. The group was formed in response to the waste management problems in the informal settlement. The group collects waste from the neighbourhood and separates the waste, recovering recyclables for sale. The initiative is sponsored by Practical Action and it received support from Epworth Local Board thereby allowing the smooth running of the project. Push-carts are used to collect waste and recovered waste material is sold to waste recycling companies. Stakeholders should come up with a national waste management strategy and guidelines which will be adopted and implemented by all local authorities in the country. There is need to network, 
cooperate and interact with the aim of finding participatory and practical long lasting solutions to the current waste management challenges. Safer Environment (2009) contends that waste reduction and raw material conservation are the most important functions of waste management.

Waste generation is a function of inefficient use of resources. In industry, it costs business money because of failure to gain the desired benefits by using more raw materials and payment of disposal costs for wastes. Besides, the environment gets dirtier, causing lots of air, land and water pollution and other related nuisances. Wastes also represent the inefficient use of services such as electricity, water and fuel which are often considered unavoidable. Other losses incurred via wastes are the purchase of wasted raw materials, management time spent on waste materials and lost revenue on what could have been a product.

\section{Legislative Framework}

The legislative framework for managing waste is in place in the form of the Environmental Management Agency (EMA) (Cap 20:27), the supreme environmental law of the country .Environmental law in Zimbabwe criminalizes littering by individuals and companies. Anyone caught littering is liable to a fine or imprisonment. Concern has been raised about the non-enforcement of the Act. There appears to be some apparent reluctance by government departments and agencies to prosecute local authorities that violate provisions of the legislation. The slow implementation of EMA is a concern especially given that it repealed some acts. Legislation alone will not solve the waste management problems as there is need for accompanying national strategies and action plans. Local authorities should be urged to support community-based waste management initiatives rather than use bylaws to suppress them. Awareness raising and public education to mitigate negative attitudes and perceptions of waste management should also be taught at schools. It is prudent to catch the pupils at a young age, advising them that action by one person makes a difference. In addition, youngsters, together with adults should be encouraged to think globally and act locally. There too is need to establish collection and recycling centres throughout the towns and start small enterprises to process waste. Stakeholders should network and add value to projects being undertaken by partners rather than repeating the same efforts all over again.

There is need to create space for other waste management models. Local authorities should create an enabling environment for formalized waste collection and recycling. Trading in waste can also be adopted as a strategy in waste management. The idea is to reduce the waste load that finds its way into the environment and also promote waste as an asset. There could be wisdom in establishing producer-user partnerships (waste networking).Economic and 
environmental benefits will accrue to industries and communities. Waste minimization clusters could come in handy. These are voluntary stakeholder networks established to promote best available practices in waste management though they require some technical back up from non-governmental organizations. There is need to emphasize waste prevention and the productive use of waste.

Experience in many countries indicates that business in a range of industries can save about $10 \%$ of turnover by emphasizing waste minimization technologies. For example, it is prudent to design packaging that can be re-used, use any waste that you produce until it no longer has any value and then recycle the waste. Customers, employees and potential investors are all becoming more aware of environmental responsibility and failure to take action could affect one's business. Source reduction is identical to waste prevention. In waste management, more emphasis should be placed on the biodegradable fraction and not the recyclables in order to make action at source beneficial to municipal solid waste management. The widespread collection and reuse of everyday waste materials should provide the sorting of waste into common types so that raw materials from which the items are made can be reprocessed into new products. Some waste management experts have argued that the present system has flaws and that a thoroughly effective waste management system still needs to be worked out. Source reduction involves efforts to reduce waste and other materials by modifying industrial production. Its methods involve changes in manufacturing technology, raw material inputs and product formation. It also entails increasing incentives for recycling. Many communities in the USA are implementing variable rate pricing for waste disposal (Also known as Pay As You Throw $\{$ PAYT $\}$ ) which has been effective in reducing the size of the municipal waste stream. Pre-payment to induce recycling can also be instituted. Yet another way of reducing waste generated is to charge disposal fees that are proportional to the frequency of waste collection. Related to this is the idea of reusing discarded items through the principle of 'hand me down', garbage sales, composting in addition to repair, regift and up-cycle.

\subsection{Promoting Sustainable Waste Management}

More than ever before, there is an express need for promoting sustainable waste management. This can be achieved through adopting and implementing the following strategies:

- introduce the polluter-pays principle in city level legislation;

- develop a taskforce principle at town level with representatives from public, private and community sectors;

- provide a supportive business environment for small scale recycling; 
- engage the public through the neighborhood "clean-up" campaigns;

- ensure that recycling is embodied in the school curriculum nationally and

- encourage industry to reduce non-essential packaging.

So waste management must be emphasized and should be linked to poverty alleviation, community participation and job creation. Often, there is an informal sector of refuse collectors and scavengers that has developed livelihood from collection and sales of waste materials. Imitating western technology and equipment in this sector is misguided. It does not make economic or social sense for the poor. Adopting western waste management systems by LDCs reduces access of garbage and displaces refuse collectors and scavengers who end up poorer than before the development plan was implemented (http://www.org/uem/waste/waste defined html).In any case, households in LDCs do not sort their garbage as is done in industrialized countries so the adopted technology will simply collect to dispose all the waste without recovering reusables and recyclables. There is increasing evidence that community-based approaches to waste management can promote a more sustainable development. Grass-root efforts can be more successful than top-down programmes created by bureaucrats or experts with little or no community participation. Perhaps a data base on wastes that are available will provide information to possible waste users. A change to less waste generation with use of less polluting products and cultivating habits with deep and broad education are encouraged to understand the extent of the independent ecological problems. Producers' take back campaigns and customer service marketing strategies will foster change in lifestyles. Communities and community organizations are in a perfect position to make a major impact on the amount of waste that is generated in their societies (http://www.org/uacm/waste/community-waste.html.).

Collective voices of such groups can persuade government officials to notice the problem and can influence industry to be more mindful of its responsibilities. In terms of policy, there is need to encourage local and national governments to create comprehensive and effective waste management policies and regulations for one's community and the country at large in accordance with international environmental and health standards. Citizens can monitor waste activities in their communities, get involved in education by way of organizing education campaigns through the media/schools or even going door -to - door informing the citizenry to change its values and lifestyles so that urban waste can be reduced. There may be need to communicate environmental concerns to one's local politician, invariably a councilor.

At individual level, there is need for all of us to be environmental watchdogsalerting one's local environmental protection agency to incidents of environmental abuse, notify the media of the status of environmental importance, and develop a 
rapport with journalists in one's area. There is need for us all to adopt the four "Rs" (Recover, Recycle, Reuse and Reduce) formula.

At management level, there is need to create a win-win situation through separation and sale of household materials. Households get extra cash, waste traders get resources, employment is created, quantities of waste to be collected by city authorities get reduced and the environment gets cleaner. Soft loans and livelihoods assistance packages to enhance employment opportunities for socalled eco-aide (junk) shops can be provided. In the Philippines, a consultation firm established and developed a computerized data base of waste dealers and manufacturers to link up for optional trading (http://www.gdr.org.ucm.waste/key factor.html 04/08/10).

The data base could also serve educational campaigns. The corporate sector support to source separation initiatives can be achieved through sponsoring environmental improvement by providing funds to NGOs running sourceseparation and primary collection schemes. Indian cities of Bangalore, Mumbai and Ahmadabad have attempted this with a considerable measure of success (http://www.gdr.org.ucm.waste/keyfactor.html04/08/10).Similarly,manual sorting and obtaining waste from neighbourhoods where households cooperate in more thorough separation of dry and wet wastes can be encouraged .This is being done in Santa Maria, Philippines (http://www.gdr.org.ucm.waste/key factor.html 04/08/10).

\section{School Separation and Composting Programmes for public education}

Organizations to run community and school health clubs with residents and schools can be iniated.Schools can hold drives to gather recyclables to raise money for school programmes. Children can collect recyclables, sell them to waste collectors or exchange them for goods of their choice in waste collection shops-clothing, shoes etc. They get something personal (to eat e.g. pies, drinks) so a win-win situation characterized by a cleaner environment and material benefits will obtain. When these are combined with education on waste problems, there is a potential for lasting imprints at household level. Composting of organics generated in schools can be combined with education. In line with this, city councils can encourage parents and teachers' associations to form school societies. Public awareness campaigns for knowledge of waste problems and practical benefits of a clean environment and community operation should also be launched.

Clearly, the problem of solid waste management is multifaceted hence the need for an integrated approach by identifying stakeholders, key issues which comprise important stumbling blocks and making recommendations based on appropriate technologies, local information and pressing human and environmental 
concerns.The Zimbabwe Applied Health Education And Development [ZimAHEAD] observed that city councils and residents can jointly own up to the waste menace if they sit together to identify and plan on ways to solve the sanitation challenge (Matimati,2011). The AHEAD model of community health clubs can galvanise communities to take action but this would not achieve much where there is no equal commitment from the city fathers. What needs to be done first is creating a full realization that waste is everyone's problem and shifting from the 'blame game' where residents blame council for non-collection of refuse and councils blame residents for illegal dumping. The clubs would facilitate community action to bring back the glory to the cities by clean-ups which are run by communities themselves through community and school health clubs. The clubs create an increased awareness on waste related diseases as well as ways and means through which communities could take action to be safe. Jointly working with both the residents and the city health departments, an increased responsibility, accountability, control and ownership can be created within both parties. Residents can start segregating their household waste, burying the biodegradable, reusing the plastics as plant and flower pots, taking the composted refuse into their gardens as manure and very little is left to throw away. Refuse bins become lighter and council staff and trucks become better able to move the greatly reduced waste bulk.

Community Health Clubs and School Health Clubs can mobilize themselves and carry out mass clean-up campaigns that can leave our towns and cities very clean once again. Subsequent clean-ups can mop up the dwindling illegally dumped waste until such a time when almost everyone in the city becomes conscious of proper waste management and the habit of illegal dumping dies. During the clean-up campaigns, councils have to prioritise and provide waste removal vehicles in sync with the cleaning schedules.

\subsection{Commitment from the City Fathers}

Councils should measure up by providing clean-up equipment and tools, refuse removal trucks through committed Environmental Health Departments. Mutare and Masvingo City Councils have made strides in this direction. Dedicated environmental health staff was deployed to this cause hence there was improved communication between council and residents via Community and School Health Clubs. Sakubva (Mutare) and Mucheke (Masvingo) are the cleanest high density suburbs in the country at the moment owing to the common unity of purpose that prevails between the city fathers and the residents as facilitated by the Community Health Clubs. Workshops bringing together local urban council authorities, government officials, environmental management agency officials, journalists, scientists, as well as educators, researchers and members of the private sector should be organised. With respect to community groups,participants for 
such workshops should be drawn from all wards in each of the towns. They should receive training in residents leadership development that includes participatory budgeting, the Urban Council's Act and the Environmental Management Act.

Such stakeholders' workshops should deliberate on practical solutions to the waste management challenges bedevilling local authorities. Themes for such workshops should revolve around the crafting of a battery of measures aimed at addressing solid waste management such as integration and sustainability of waste management regulations in urban areas. Papers presented should cover a wide range of aspects of waste management regulations and provide many useful examples. Reports detailing findings of review studies undertaken on the legislative and policy framework for waste management in Zimbabwe, with special reference to specific towns and cities, can be quite helpful. Such studies should seek to evaluate the policy and legislative framework governing the management of waste in Zimbabwe with special focus on the areas mentioned above. This must cascade to lower tiers of local authorities. Weekly public consultations with interest groups being invited to the civic centre, town house or ward centres could be an effective way of getting the citizenry to be actively involved in waste management. At such consultative meetings, effort should be made to empower urbanites in the areas of service delivery and local governance. Training workshops should be mounted where residents get trained in leadership, local governance, peace building, elections, public policy and advocacy, and documentation.

City councils and other stakeholders should run solid waste management programmes with a view to raise awareness about safe waste management practices in addition to finding innovative ways of curbing pollution. Councils should line up a number of programmes designed to improve solid waste management in towns and cities. In such programmes, it is good to involve communities. Under such programmes, universities, research institutes and councils could hold a series of workshops on waste management with waste generators. Other stakeholders such as the National Social Security Authority (NSSA), the Environmental Management Agency (EMA) and legislative bodies would have to be invited to such workshops to conscientise industry about the waste management practices so as to avoid pollution and diseases. Stakeholders should think in other terms with regards to environmental protection and keeping our towns clean. Industrialists should be urged to develop systems to pre-treat water before disposing of the waste into our systems. A partnership within industry would also go a long way in changing the pre-treatment facilities which are available, and also provide an opportunity to explore new ways of pre-treating waste. Such workshops with industry would cover aspects like industrial effluent 
and human health, monitoring of industrial effluent, legislative framework and waste management technologies.

The debate around waste management is a topical issue which calls for contributions and attention from all of us as waste management is everyone's concern. There is need to walk the talk on environmental protection and the sustainable use of natural resources, the environmentally sustainable way of consuming, disposing, recycling and discarding waste. This way research centres would assist in giving necessary solutions to existing problems. Organisations like Banc $A B C$ Bank played their role by donating waste vehicles, fuel is readily available but the problem still persists. If we rope in communities and teach them that there is money and, of course, health problems in waste, then we are able to fight the waste challenge. While it is imperative to work with communities, it is equally important to incentivise them as they would always ask: 'What's in it for me?' Now, more than ever before, there is need to move away from standard to innovative systems of using our resources.

Public urination and defecating laws are primarily governed by state and local bylaws. In Zimbabwe, the laws exist but many people usually get away with it as is usually witnessed mainly around bottle stores, beer halls as well as at any vending place including in the central business districts (CBDs). Tightening public defecating and urination laws is necessary to curb the growing problem of human waste on city streets as well as to promote and keep a clean and health environment. The issue of waste accumulation needs to be examined on its own as living conditions in most urban areas are not pleasant for humans especially living in such a rich country as Zimbabwe. Municipalities should take heed of residents' and concerned organisations' appeals to keep our environs clean as dirty surroundings endanger the lives of many people who, ironically, pay the rates that sustain them. Town Councils and research institutions can sign memorandums of understanding that enable such organizations to work together in areas of research and development of the towns. Working in partnership with communitybased organisations (CBOs) and local authorities, initiated projects should use an integrated approach in addressing waste management challenges facing urban settlements. Focus should be placed on improving the urban environment through developing sustainable, community-managed models for water, sanitation and waste management services. However, local authorities should put in place collection methods that would ensure that waste is collected on a regular basis. Initiatives should be put in place to ensure that segregated waste can be recycled or reused before the residual is disposed of via landfill or other means.

Waste separation at source is a brilliant idea. Environmentalists are advocating for "separation at source". It involves households binning plastics, food and metal separately, a practice that is popular in developed countries. The waste disposal method is however costly since it requires more bins, yet municipalities are 
battling to provide just one. Residents would have to supply their own bins.Most countries are recycling waste especially plastics that are used to manufacture a number of products such as T-shirts, diesel, candle-wax and crayons, among others. Renowned sportswear manufacturer Nike, produced jerseys for the Brazilian and US senior football teams during the 2010 World Cup in SA.It is against this background that the decision by the Environmental Management Agency (EMA) to fine Harare City Council for discharging raw sewage into the environment should be welcome. While the US\$15000 fine is nothing compared to the magnitude of the problem at hand, it is a positive step that shows that EMA has awoken from its deep slumber and is finally acting to stop the rot.EMA should not end there. It should step up its policing duties to ensure that all councils comply with environmental laws. Too many councils are disposing solid waste at undesignated sites without disposal licences. The responsible authorities should find ways of integrating with various organisations and stakeholders to find an effective everlasting solution to waste handling and management.

Waste management should be declared a national disaster to allow for urgent resource mobilisation to rehabilitate and revitilise them (Machivenyika,2012).This would allow Government, civil society and the private sector to co-operate in addressing waste management challenges in the country and putting it back into operation.The project hinged on building the capacities of communities to improve their environment, create employment and generate income from waste management. In a country where protecting the environment is hardly a priority, there is need to create some awareness of the impact of waste on the environment. Footages showing streets and roads littered with garbage left behind by travelling and pick nicking public and by the residents themselves could come in handy as well. A rubbish exhibition meant to alert the public to the impact of consumerism on the environment can be launched as was done by the city of Bucharest, Romania (News 24, 24/11/10). The public need to be educated that everything they see in the shop from the smallest to the biggest objects, from the most desirable to the most useful ones will turn into waste. Every single gesture, every single wish to buy something generates rubbish which someone else must find a way to deal with. Exhibitions can be mounted to state the path of garbage collection to recycling, from TV sets and computers to used bulbs and plastic bags. Art work, including sculptures and pieces of furniture made of beer cans and bottle caps can also be shown at the exhibitions. The Environment Ministry and several NGOs can organize a national housekeeping day, as happened in Romania, during which volunteers clean up fields, forests and rivers. (News 24,24/11/10@21:11 Rubbish exhibition highlights waste) 


\section{Conclusion}

Waste management in Zimbabwe is the responsibility of local authorities. The major municipalities are reported to be operating at about $40 \%$ of refuse collection and disposal capacity and practically $0 \%$ in terms of processing. Financial constraints and limited technical capacity have resulted in an accumulation of waste in Zimbabwe's major cities and towns. Consequently, Zimbabwe today is under the severe strain of litter. This poses a health risk to the country. The problem has become so endemic that many Zimbabweans have now accepted this as way of life. Sadly, we are bequeathing this to coming generations. Government would welcome investment from waste collection and waste processing companies which could offer services and technology transfer to local authorities in Zimbabwe. It is imperative that authorities provide more rubbish bins and put in place more public toilets for the benefit of the public. Government and environmentalists should go into over-drive in calling upon all Zimbabweans to avoid littering to reduce the outbreak of diseases. There is need to change the mind-set of Zimbabweans to one where litter is everyone's concern. Such a programme's success is pillared on infrastructure development and culture change among Zimbabweans as poor waste management systems currently practiced by Zimbabweans contribute to severe environmental deterioration countrywide and disease outbreaks.

The World Environment and Health Days should be meaningfully celebrated. NGOs, Government, Corporates and Communities should on such days make commitment statements on eradicating waste in the country. Litter is a state of mind, a moral issue and is directly related to our character as a nation. In order to achieve "zero litter", the public's perception of litter must change. It is the mind-set that is the root-cause of the habit. Marches could be held across the country sensitizing the public about the dangers of poor waste management. On such occasions, identified stakeholders make speeches relating to the days and the need to eradicate litter in Zimbabwe. Such events should be attended by the entire spectrum of the population. It is prudent to roll out a zero litter programme starting with country-wide zero litter conferences. Subsequent to such conferences, zero litter action plans could be initiated. The idea will be to change the public's attitude on refuse disposal. In line with this, it would be rewarding to initiate positive talk on public social responsibility and a separate at source campaign in Zimbabwe Stakeholders including various ministries (including though not limited to Education, Arts. Sports and Culture, Media, Information and Publicity, Tourism and Hospitality Industry, Environment and Natural Resources, Health and Child Welfare, Local Government and Rural Development) that are central to the successful completion of such a programme, the local business community, the United Nations Development Programme and environment Africa need to be engaged so that the country begins a generation of litter conscious Zimbabweans. Meanwhile recycling initiatives across the country can also be initiated. 


\section{References}

Awoso, J.A.; Taiwo, A.M.; Gladebo, A.M. and Arimoro, A.O. (2010) "Waste Disposal and Pollution in Urban areas; A workable remedy for the Environment in Developing Countries" in American Journal of Environmental Science, 6(1) pg26-32

Barton, J.R; Issaisias, I and Stenford E.I. (2008) "Carbon-Making the right choice for waste management in developing countries". Waste Management 28:690-698.

Booth, Martin, K. and Lankester, T. (2001) Urban Health and Development: A Practical Manual for use in Developing Countries, Oxford, Macmillan Education.

Botkin, D .B. and Keller, E.A. (2000) Environmental Science: Earth as a living Planet, New York, John Willey.

Burian, B.and AlphonceT.K. (2000)Sustainable Development in an Urban Tanzanian Context,http://www.unrsid.org.unrisd/website/document.nsf/ (http Publications)/EICC5E17A541FO84C1256F3C0040657D? 0penDocument

Chari ,E. "Working with Communities in Waste Management Proceedings of the Emerging Issues in Urban Waste Management Workshop organized by Practical Action for Southern Africa, Newlands ,Harare, at Jameson Hotel,10 February,2006

Central Statistical Office (2002) Census 2002.Zimbabwe Preliminary Report. Harare: Government Printers.

Chidavaenzi, M. and Kwenda, G. (2006) "Research and Research gaps in waste management" (2006).Proceedings of the Emerging Issues in Urban Waste Management Workshop organized by Practical Action for Southern Africa, Newlands ,Harare, at Jameson Hotel,10 February,2006

Chikuruwo,J.(2006) "Immerging Issues in Urban Waste Management "Proceedings of the Emerging Issues in Urban Waste Management Workshop organized by Practical Action for Southern Africa, Newlands ,Harare, at Jameson Hotel,10 February,2006.

Chiwandamira, L. (2000) Environmental Policy, Harare, Zimbabwe Open University.

Cointreau, S.J. (1982) Environmental Management of Urban Wastes in Developing Countries: A Project Guide. Urban Development Department, World Bank, Washington DCISBN082130036, pp: 214

Federal Environment Protection Agency, (FEPA), (1998) Bauchi State Environmental Action Plan. A World Bank Funded Project for the Federal Environment Protection Agency, Geomatics Nigeria Limited, Nigeria,

Green Living Tips, (2009) Waste decomposition rates.www.greenlivingtips.co/articles/311/1/Waste-decomposition-rates.html.

http://www.gdr.org.ucm/waste/3r.html

http://www.gdrc.org/ 04/08/10

http://www.gdr.org.ucm.waste/key factor.html 04/08/10

http://www.gdr.org.ucm/waste/waste defined.html

http://www.gdr.org.uacm/waste/community-waste.html

Intergovernmental Panel on Climate Change (IPCC)(2006) Guidelines for National Greenhouse Gas Inventories. In: Waste Generation, Composition and Management Data, Pipatti, R., Alves, S...Goa, Guendehou G.H.S and Koch, M (Editors)

Intergovernmental Panel on Climate Change (IPCC), IPCC /OECD/EIA,Paris,France.http://www.mendeley.com/research/chapter-2-wastegeneration-composition-and-management-data 2006/

Ireen, T.A. (2008) "Solid Waste Management, Potentials and Challenges, Internet Edition, 28, July, 2008 in The New Nation.

Jackson, A.R.W. and Jackson J.M. (1998) Environmental Science: The Natural Environment and Human Impact, London, Longman 
Kativhu (2006)Proceedings of the Emerging Issues in Urban Waste Management Workshop organized by Practical Action for Southern Africa, Newlands ,Harare, at Jameson Hotel,10 February,2006

Katyal, T.and Satake, M. (2001) Environmental Pollution, New Dheli,Anmol Publications Pvt.Ltd. Makoni, F.S, Ndamba,J., Mbati,P.A.and Manase,G. (2004) "Impact of waste disposal on health of a poor urban community in Zimbabwe".East African Medical Journal 81 (2004) 422426. http://ajol.info/index.php/eamj/article/view/9204

Makwara,E.C.(2011)Work Related Environmental Health Risks:the case of garbage handlers in the city of Masvingo,Lambert Academic Publishing, Saarbrucken.

Mapira,J.(2012) "Challenges of solid Waste Disposal and Management in the city of Masvingo"Journal of Social Development in Africa,Vol.26,No.2 2011 pg 67-91.

Mapira,J.(2007) Pollution of the Sakubva River,Mutare(Zimbabwe): Culprits,Penalties and Consequences,Zimbabwe Journal of Geographical Research,Vol.1 Nos.33/34 pp 9-19

Mapira,J. and Mungwini,P. (2005)River Pollution in the City of Masvingo:A Complex Issue,Zambezia Vol.32.Nos.1/2 pp 95-

Matimati,R.(2011)Urban Waste management in Zim "City Authorities and Residents Joining Up"19 ,December,2011

Miller,T.(1994)Living in the Environment:Principles, Connections and

Solutions,Califirnia,Wardsworth Publishing Company.

Moyo,A.(2011)“EMA, IES on waste management"Proceedings of the Emerging Issues in Urban Waste Management Workshop theme "Waste management strategy: Fostering partnerships for improved solid waste management in Zimbabwe” ,Harare,10, December, 2011

Muchadenyika, D. (2012) "Improved local governance answer to service delivery"

Daily News on Sunday, Zimbabwe: 12 August 2012.p.11

Muza,E.(2006) "Challenge Proceedings of the Emerging Issues in Urban Waste Management Workshop organized by Practical Action for Southern Africa, Newlands ,Harare, at Jameson Hotel,10 February,2006

Newsday, 8 June, 2012 News 24,24/11/10@21:11 Rubbish exhibition highlights waste

Nhete,T. (2006)Proceedings of the Emerging Issues in Urban Waste Management Workshop organized by Practical Action for Southern Africa, Newlands ,Harare, at Jameson Hotel,10 February,2006

Nkatazo, L. http//newzim.proboards86.com 08/08/10

Population Reference Bureau, 2011

Saferenvironment (2009) PARTHA DAS's Weblog on keeping the world environment safer and greener

The Chronicle, 21 March 2012 "Nust launches safe waste management programme" The Chronicle Reporter

Machivenyika, F. "Declare city sewage plants a national disaster — group” The Herald,31 March 2012.

United Nations Economic and Social Council for Asia and the Pacific Committee on Poverty Reduction Third Session29/11-01/12/2006 "Community -Based Solid Waste Management"

United Nation Environment Programme (UNEP)-International Environment Technology Centre (2003) 'Urban Waste Management Strategy.'

Zerbock, O. (2003) "Urban Solid Waste Management; Waste Reduction in Developing Nations.’Unpublished Masters' Thesis. 